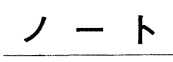

\title{
無電極型水晶発振子を用いる一滴法によるシュウ酸 イオンの定量
}

\author{
野村 俊明 ${ }^{\circledR}$ ，啮川 陽子* \\ (1994 年 4 月 11 日受理)
}

\section{1 緒言}

無電極型水晶発振子は, 従来の水晶発振子の両極の電 極の代わりに電解質溶液を㯰き, それぞれの溶液中に才 シレーターからのリード線 (電極) を挿入したもの゙で ある。この無電極型水晶発振子も, 従来の水晶発振子 ${ }^{2)}$ と同様に, 電解質溶液の液温や液性により基本振動数が 変化すると同時に，水晶振動子上に付着した物質の質量 に依存して振動数が変化するので, 沈殿を生成して水晶 振動子上に付着する反忑, 例えば硫酸イオンとバリウム イオンとの片忍を利用すれば，イオンの定量法として利 用できる31. しかも, 電解質溶液は一滴あれば十分であ るので, この電解質溶液を試料溶液に置き換えた場合, 微量な試料溶液中の成分が定量できることになる.

植物成分の中で, 沈殿法により定量できる成分は多々 あるが，今听はュウ酸イオンに着月した。シュウ酸イ オンはイオンクロマトグラフィー', 電気化学ルミネセ ンス法5など，種々の方法により测'㳬法が検討されてお り, 植物中のシュウ酸イオンの抽出法も詳細に検討され ている゙). 今[门は们しの抽仕法を基本にして, 一滴法に適 した試料調製法を検湖した.

\section{2 実験}

\section{$2 \cdot 1$ 試薬及び装置}

試薬はすべて市敗特級品（利光純薬卫.業製）を用いて 保存溶液を調製し，使用の都度適宜希釈した。

水はすべてオートスチル（ヤマト科学製，WG-25） により調製したイオン父換水を册いた。

シュウ酸イオン標準液は, 特級シュウ酸ナトリウム (和光純薬丁.業製) の…定量をひょう取して, $0.1 \mathrm{M}$ 保 存液を調製し，使用の都度適宜希釈した。

水晶振動子 (水晶板) は, $\mathrm{AT}$ カット, $9 \mathrm{MHz}$ の正

* 雇州大学理学:部化学教宰: 390 長野県松本市旭 3-1-1
方形 $\left(8 \times 8 \mathrm{~mm}^{2}\right)$ のものを用い, 水滴が再現性よく水 晶板上に載るようにするために，塗布剤としてパラフィ ン（和光純薬工業製，m. p. $60 \sim 62^{\circ} \mathrm{C}$ ）を水晶板にこす り付け, ペーパータオルで均一になるようにふいて使用 した. パラフィン処理した水晶板を取り付けたセル は, $20.0 \pm 0.1^{\circ} \mathrm{C}$ の恒温槽（ヤマト科学製, CTE-22A) 中のビーカー内に入れ，アクリル板でろたをした。 セル からの電極端子はオシレーター（ノーマル TTL）に接 続して，定電圧電源（メトロニクス製，523B）によ り，5.0 V を印加した。 オシレーターは周波数計（アド バンテスト製，TR5824）に接続し，ゲイトタイム 0.1 秒で振動数を計測するように設定し，記録計（東亜電波 工業製，EBR-251A）に接続した。

\section{$2 \cdot 2$ 定量操作}

一滴法用に処理した水晶板をセルに装着し, 電極とし ての銅板と対極としての白金線との間隔を $1.0 \mathrm{~mm}$ に調 節する ${ }^{3)}$. $5.0 \mathrm{~V}$ の電圧をオシレーターに印加する。 $0.25 \mathrm{M}$ 塩化カリウムと $0.025 \mathrm{M}$ 酢酸一酢酸ナトリウム ( $\mathrm{pH} 4.6$ ) とを含む $0.05 \mathrm{M}$ 塩化カルシウム溶液を $5 \mu \mathrm{l}$ 水晶板上に滴下する．振動数が一定になったら， 0.25 $\mathrm{M}$ 塩化カリウムと $0.025 \mathrm{M}$ 酢酸一酢酸ナトリウム $(\mathrm{pH}$ 4.6）とを含むシュウ酸イオン試料溶液を， $5 \mu \mathrm{l}$ セルに 取り付けたマイクロピペットで滴下する. 滴下直後と 3 分後の振動数を周波数計から読み取り，3 分間の振動数 変化量を求める. シュウ酸イオン標準溶液を用いて，作 成した検量線からシュウ酸イオン量を求める.

\section{3 結果及び考察}

\section{$3 \cdot 1$ 塗布剤の検討}

既報 ${ }^{3)}$ に従って, テフロンを吹き付けた水晶板は, 水 滴を再現性よく水晶板上に載せることが可能であるが， 塗布面にむらが生じやすく, 試料溶液滴下直後の振動数 変化の再現性に乏しい。 そこで，水晶板全面にテフロン 
を吹き付けた．水滴位置の再現性は水晶板上の中央に白 金線電極を位置させることで解決し, 試料溶液滴下時の 振動数変化の再現性も改善された. しかし, 1 回の塗布 で使用できる回数は約 5 回であり, 実用性に乏しかっ た。これは, 水晶板上に付着しているテフロンが, 使用 中に脱落してしまうためと思われる.

本実験では, 溶液が水晶板上で再現性よく水滴状態に なることが必要である．この条件を満たすはっ水郕とし て, シリコーン接着シール材（東芝シリコーン製, TSE382-C) を紙につけ水晶板に塗布したが, 塗布量が 多すぎたためか発振しなかった。次に, 固形パラフィン を水晶板上に軽くこすり付け，ペーパータオルでふき， 水で洗って使用した。テフロンに比べ試料溶液滴下時の 振動数変化量が約 3 倍に増え, しかも約 20 回の使用に 耐えるようになった，再現性が悪くなった場合の再塗布 は, クロロホルムによってパラフィンを溶解除去後, エ タノール, アセトンの順で洗浄して乾燥した後に行う. なお，パラフィン塗布の均一性を，ペーパータオルでふ くのでなく, 高温にして融解処理することで得る試みは 成功しなかった。

\section{$3 \cdot 2$ シュウ酸カルシウムとしての付着}

シュウ酸カルシウムは中性から弱アルカリ性において 沈殿する. 従って, 中性付近の $\mathrm{pH}$ を中心に水晶振動 子上への付着を検討した. 電解質として $1 \mathrm{M}$ 塩化カリ ウム溶液と, 緩衝溶液としての $0.1 \mathrm{M}$ 酢酸一酢酸ナトリ ウム溶液とを $1: 1$ で混合し,そこに沈殿剤としての $0.1 \mathrm{M}$ 塩化カルシウム溶液を等容加えた溶液の $5 \mu \mathrm{l}$ を 水晶板上に採る. 振動数が安定した後, 上の混合液と等 容のシュウ酸イオン標準溶液とを加えた試料溶液を $5 \mu \mathrm{l}$ 滴下して, 生成したシュウ酸カルシウムの沈殿の付着に よる振動数変化量を求めた (Fig. 1). 検討した $\mathrm{pH}$ 4 8 (ホウ酸-水酸化ナトリウムを使用) において, 沈 殿付着による振動数変化が認められたが, $\mathrm{pH} 4.1$ から 5.6 までは振動数の変化量は增大して, $\mathrm{pH} 8.1$ ではわず かに減少した。これは前者においては沈殿生成が不完全 なためであり，後者においては沈殿がすぐに安定化する ために, 水晶振動子上に付着しないためと思われる. し かし, 実試料の前処理には酢酸を用いることが好都合で あることと，酢酸と等モルの酢酸ナトリウムを加えれば 簡単に $\mathrm{pH} 4.6$ に調整ができることを考えて, 酢酸一酢 酸ナトリウムによる $\mathrm{pH} 4.6$ を用いることにした.この $\mathrm{pH}$ において検量線を求めたところ，0.5 10 mM の間 で, シュウ酸イオン濃度 $(C, \mathrm{mM})$ と振動数変化量 $(\Delta F, \mathrm{~Hz})$ との間に直線性, $\Delta F=94.8 C+80$, が得ら

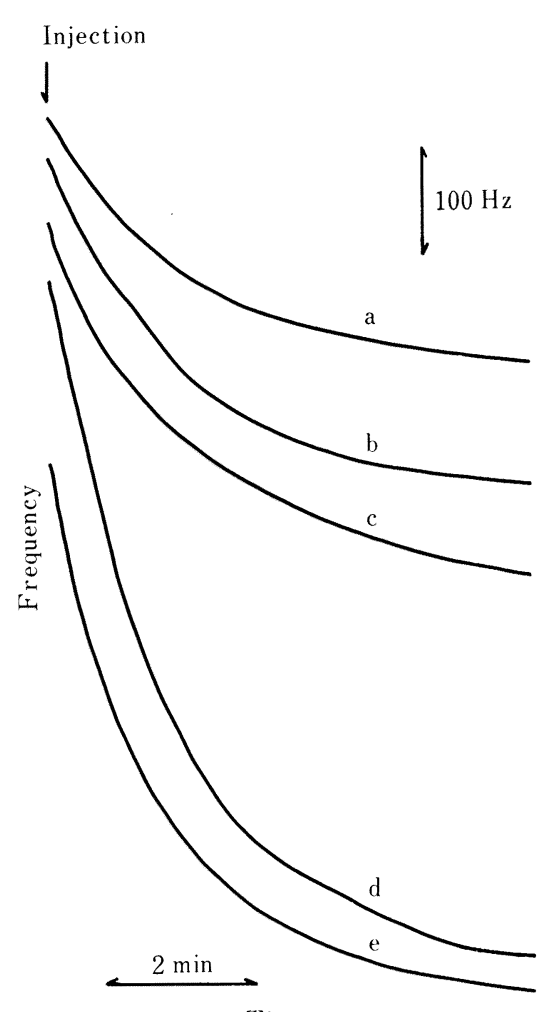

Fig. 1 Dependence of the frequency change on $\mathrm{pH}$ after injection of the standard oxalate solution (2.5 $\mathrm{mM}$ ) on the quartz plate $\mathrm{pH}: \mathrm{a}, 4.1 ; \mathrm{b}, 4.6 ; \mathrm{c}, 5.1 ; \mathrm{d}, 5.6 ; \mathrm{e}, 8.1$

れた. $5.0 \mathrm{mM}$ シュウ酸イオン標準溶液での相対標準偏 差は, $9.3 \%(n=9)$ であった.

\section{$3 \cdot 3$ 実試料中のシュウ酸イオンの定量}

実試料として、ホウレンソウを朋い，シュウ酸イオン の定量法を検討した。ホウレンソウからのシュウ酸イオ ンの抽出は $\mathrm{Ishii}^{4)}$ の方法に従った。

$10.0 \mathrm{~g}$ の試料を $50 \mathrm{ml}$ の水で 20 分間沸騰した後, 沪 紙 No. 5B で沪過して一定容にし, 更にその一部を 0.2 $\mu \mathrm{m}$ のメンブランフィルターで沃過して试料溶液とし た。この溶液は沈殿剤を加えなくても, 付着による振動 数変化が認められた。これは, 武料溶液に加えた酢酸一 酢酸ナトリウムや塩化カリウムのために, 不特定物質が 析出して水晶板上に付着するためと思われる。この不特 定物質の除去と抽出とを一度にするために, ホウレンソ ウに $0.1 \mathrm{M}$ 酶酸溶液を加えて, 20 分間沸騰した後, 沪 


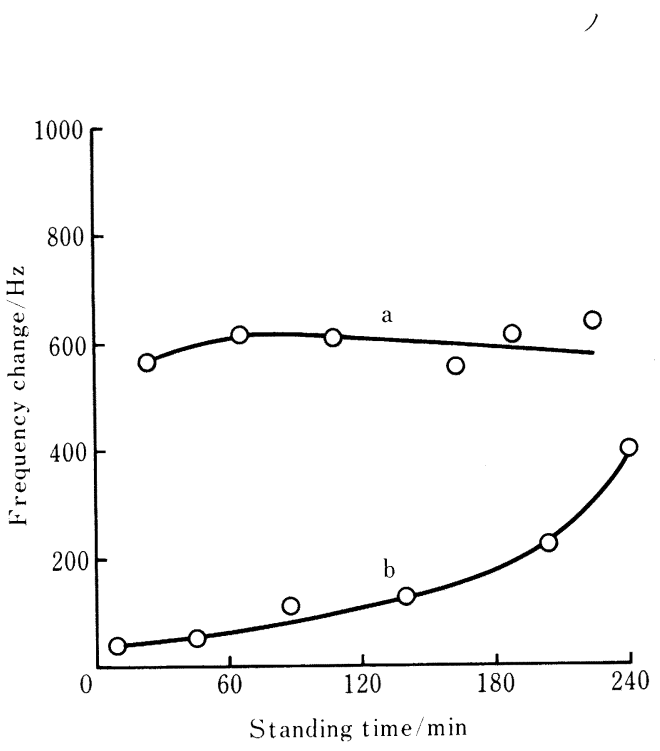

Fig. 2 Dependence of the frequency change on the standing times after filtration of a spinach extract The measurements were carried out with (a) and without (b) calcium chloride.

過して振動数を测定したが，塩化カルシウムを加えない ときでも付着による振動数変化が認められ，酢酸による 不特定物筫の除去が行われていないことが分かった。 そ こで，この物質を取り除くために，沸騰後洰紙 No. 5B で汗過し， $50 \mathrm{ml}$ の $0.1 \mathrm{M}$ 酢酸溶液を加えて水で全容を $100 \mathrm{ml}$ にして一晚放置後, $0.2 \mu \mathrm{m}$ のメンブランフィル ターで沂過し, 测定したところ不特定物質の付着が生じ なかった。なおメンブランフィルターで洰過後は, 90 分を過ぎると沈殿剂としての塩化カルシウムを加えなく ても付着が始まるので, 沃過後は1時間以内に測定す るこ上が必要である (Fig. 2). 以上より，ホウレンソ ウ中のシュウ酸イオンの定量は次のようにした。

$10.0 \mathrm{~g}$ のホウレンソウを手でちぎり, $50 \mathrm{ml}$ の水を加 え 20 分間沸騰する.沃紙 No. 5B で沪過し, $50 \mathrm{ml}$ の $0.1 \mathrm{M}$ 酢酸溶液を加えて, 水で全容を $100 \mathrm{ml}$ にして一 晚放置する。 $0.2 \mu \mathrm{m}$ メンブランフィルターで沪過し， この沪液を試料溶液とする。七ルに滴下時には, 試料溶 液 $10 \mathrm{ml}$ に $1 \mathrm{M}$ 塩化カリウム浴液 $5 \mathrm{ml}, 0.1 \mathrm{M}$ 酢酸ナ トリウム溶液 $5 \mathrm{ml}$ を加えて混合後, $5 \mu \mathrm{l}$ を分取してセ ル中の水晶板トに滴下し, 定量操作に従ってシュウ酸力 ルシウム沈殿の付着による振動数変化量を測定した.
以上の操作に従って, ホウレンソウ中のシュウ酸イオ ン量を求めたところ, $10 \mathrm{~g}$ 中に $126 \mathrm{mg}$ 含まれているこ とが分かった，又，同じ試料を標準添加法により求めた ところ, $118 \mathrm{mg}$ が含まれていることになった。

ホウレンソウ中のシュウ酸イオン量をイオンクロマト グラフィーによって確認した。用いた装置は島津製 LC-9A, CTO-6AS で, 検出器は電極分離型水晶発振子 を用いた ${ }^{6)}$. 又, SCR-102H 分離カラムとガードカラム を使用し, 移動相には水, 流量 $1.5 \mathrm{ml} \mathrm{min}^{-1}$, オーブ ン温度 $40^{\circ} \mathrm{C}$ で测定した。

ホウレンソウを水で 20 分間沸騰し, 洰紙 No. 5B で 沃過後, 直ちに $0.2 \mu \mathrm{m}$ のメンブランフィルターで沃過 し，これを試料溶液としてイオンクロマトグラフに注入 した. シュウ酸イオンに基づくピークは約 3.2 分後に現 れ，このピークの振動数変化量から，検量線法によりホ ウレンソウ中のシュウ酸イオン量を求めたところ, $10 \mathrm{~g}$ 中に $120 \mathrm{mg}$ 含まれていることが分かり，一滴法の結果 とよく一致した。一方, 野菜ジュース中のシュウ酸イオ ン量を求めるために，ジュース $5 \mathrm{ml}$ を採り，ホウレン ソウのときと同様に処理して, 一滴法及びイオンクロマ トグラフィーで測定したが, 振動数変化が認められず, 使用した野菜ジュース中にはシュウ酸イオンが含まれて いないことが分かった．以上のように，一滴法により植 物中のシュウ酸イオンを定量することができた．本法 は, 今までに報告されている沈殿形成を手段としている 定量法に適用でき，しかも装置も簡単であり，定量操作 も迅速簡単で試料量もわずかであるので, 多方面への適 用が可能である.

$\left(\begin{array}{l}1993 \text { 年 } 10 \text { 月, 日本分析化学会 } \\ \text { 第 } 42 \text { 年会にて一部発表 }\end{array}\right)$

\section{文献}

1) T. Nomura, F. Tanaka, T. Yamada, H. Itoh: Anal. Chim. Acta, 243, 273 (1991).

2) J. J. McCallum: Analyst (London), 114, 1173 (1989).

3) T. Nomura, Y. Ohno, Y. Takaji: Anal. Chim. Acta, 272, 187 (1993).

4) Y. Ishii: Anal. Sci., 7, 263 (1991).

5) N. Egashira, H. Kumasako, Y. Kurauchi, K. Ohga: Anal. Sci., 8, 713 (1992).

6) T. Nomura, T. Yanagihara, T. Mitsui: Anal. Chim. Acta, 248, 329 (1991). 
is

Determination of oxalate by the single drop method using an electrodeless piezoelectric quartz crystal. Toshiaki Nomura and Yoko Shibukawa (Department of Chemistry, Faculty of Science, Shinshu University, 3-1-1, Asahi, Matsumoto-shi, Nagano 390)

The single drop method using an electrodeless piezoelectric quartz crystal (PQC) was able to be applied to the determination of oxalate, in the form of calcium oxalate, in spinach extract. Setting an electrodeless quartz plate, which was treated with paraffin, on the copper plate electrode in a cell, a drop of $5 \mu \mathrm{l}$ of calcium chloride solution containing potassium chloride and acetate buffer was applied. A platinum wire of a counter electrode was inserted into the drop at $1.0 \mathrm{~mm}$ distance between the plate and the top of the wire electrode, and the system was left until the oscillation frequency of the electrodeless PQC became constant. The oxalate sample solution of $5 \mu$ l containing potassium chloride and acetate buffer was then added to the drop. By reading the frequency change between just after the application of the sample solution and at 3 min later, the concentration of oxalate was estimated. Oxalate in spinach leaves was extracted with hot water by boiling for $20 \mathrm{~min}$. After passing through a filter paper, the extract was added to acetic acid and incubated over night. Then the extract was filtrated using a membrane filter, and to it was added potassium chloride and sodium acetate to adjust the $\mathrm{pH}$ to 4.6. This solution was used as the sample. The concentration of oxalate in the spinach leaves estimated by this method was in agreement with that obtained by ion chromatography.

(Received April 11, 1994)

\section{Keyword phrases}

electrodeless piezoelectric quartz crystal; single drop method; oxalate; frequency change; spinach. 